\title{
Közgazdasági tételek, amelyek áttörésre várnak
}

\section{Economic Propositions Waiting for a Breakthrough}

\section{Összefoglalás}

A tanulmány néhány olyan közgazdasági gondolatot vet fel, amelyek az alternatív közgazdasági gondolkodókat napjainkban foglalkoztatják, de nem váltak világméretekben a gazdaságpolitikák részévé. Ilyen az adekvát technológia elve, ami azt jelenti, hogy ne alkalmazzunk tôkeigényes technikát olyan gazdaságban, amelyben bôséggel áll rendelkezésre munkaerô. A másik, hogy a jövedelemeloszlás aránytalanságai akadályát jelentik a további gazdasági növekedésnek. A harmadik: megállapítható, hogy a Bretton Woods-i rendszer olyan irányba fejlódött, ami nemzetközi méretekben fokozza a jövedelemaránytalanságokat. A fejlődő országok, sôt egyes OECD-országok is súlyos adósságcsapdába estek. A jelen világrendszer trilemmájából - nemzeti szuverenitás, hiperglobalizáció, demokrácia - egyszerre csak kettő valósítható meg. Célszerúen a globalizációban kell egy lépést visszalépni. Végül megemlítjük a financializáció jelenségét, ami azt jelenti, hogy egyre nagyobb hányada a megtermelt jövedelemnek a pénzügyi szektorba áramlik. A szektor szolgából úrrá lett, a hatalmas megtakarítások válságból válságba sodorják a világgazdaságot. A tanulmány levonja a következtetést: a szabad verseny és demokrácia alapján álló kapitalizmusban a demokrácia válságát tapasztalhatjuk. Morális megújulásra van szükség, hogy megtaláljuk a fenntartható gazdaság és társadalom mechanizmusát.

Prof. Dr. Botos Katalin, professor emerita, Szegedi Tudományegyetem (evmkabor@gmail.com). 
Journal of Economic Literature (JEL) kódok: B25, B26, B27

Kulcsszavak: globalizáció, adekvát technológia, nemzeti szuverenitás, tôkemozgás szabadsága, financializáció, demokrácia

\section{Summary}

The study analyzes some economic theories which are already influencing alternative economic thinking but have yet to become part of economic policies in the world. One of these is adequate technology, which means not using capital-intensive technology in a country where the labour force is abundant. The second is income inequality, which is an obstacle to economic growth. It is not only a moral question. The third is the evolution of the Bretton Woods system, which contributes to growing economic imbalances on an international scale. Many developing countries are suffering from debt-traps. There is a trilemma in the world: hyperglobalisation, democracy and national sovereignty cannot be fulfilled all at once. Probably we have to step back a bit in globalisation. Finally, there is the question of financialisation, which means that the greatest portion of incomes is flowing to the financial sector. Finance has become the lord from the servant and the enormous savings bring the world economy into crises. The conclusion of the study is that we are experiencing the crises of the free market and democracy. We need a moral rejuvenation to find a mechanism for the survival of our economy and society.

Journal of Economic Literature (JEL) codes: B25, B26, B27

Keywords: globalisation, adequate technology, national sovereignty, freedom of capital movement, financialisation, democracy

\section{BEVEZETÉS}

Az alternatív közgazdasági gondolkodók számos olyan kérdést vetnek fel korunk irodalmában, amelyek korábban még tabunak számítottak, vagy mivel a gazdaságtudomány nem tekintette a körébe tartozó kérdésnek, a szakma egyszerúen nem tárgyalta ezeket, fôképpen pedig nem alapoztak e tételekre gazdaságpolitikát. Márpedig a közgazdaságtannak az (lenne) a célja, hogy megismerve a gazdaság törvényszerúségeit, igyekezzen odahatni, hogy egy hatékonyan múködô, sốt, igazságos piaci környezet jöjjön létre.

Mondják, hogy az igazságos jelzố nem releváns kritérium a közgazdaság-tudományban. Messze vezetne, ha e témába filozófiai mélységekig belevágnánk. Itt és most legyen elég annyi, amennyit errôl Stiglitz mondott: „a nem igazságos jövedelemelosztás nemcsak morális kérdés, hanem visszafogja a gazdasági növekedést is" (Stiglitz, 2013). Akkor talán mégiscsak a gazdasági mérlegelés körébe sorolandó!

Idézzünk fel tehát néhány olyan közgazdasági tételt, amelyek, bár egyes tételek elméletileg már korábban is megfogalmazódtak, mégsem törtek át a gyakorlatba. Nem 
jelennek meg a gazdaságpolitikában, sem itthon, sem világméretekben. Sôt, elsôsorban ott nem.

\section{ADEKVÁt TECHNOLÓGIA}

Az egyik ilyen fontos kérdés az adekvát technológia problémája. A gondolat szorosan öszszefügg a foglalkoztatáspolitikával. A tételt magát Ernst Schumacher írta le 1973-ban megjelent, Small is Beautiful (A kicsi szép) címú könyvében (Schumacher, 2014). Gyökerei azonban még régebbre nyúlnak vissza: Gandhi gazdasági tanácsadója és közvetlen munkatársa, az Angliában tanult, az USA-ban doktorált indiai közgazdász, J. C. Kumarappa már a harmincas-negyvenes években megfogalmazta a tételt (Botos, 2016a).

A foglalkoztatáspolitikát a közgazdászszakmai elit a szociológia, politológia síkjára helyezi, pedig vissza kellene utalnia a gazdasági mérlegelés körébe. Lényege, hogy olyan országokban, ahol relatíve olcsó és bóvében van a munkaeró, nem helyes széles körben az ultramodern technológiát alkalmazni, amelyhez szinte nincs is szükség emberre! Itt természetesen nem az olyan területekre gondolunk, mint a haditechnika vagy az úrkutatás, hanem a „hétköznapi” élet szükségleteire. A csúcstechnológiában értelemszerúen szükség van a gép abszolút pontosságára. A tơke szempontjából persze lehet másutt is értelme a munkaerôt kiváltó stratégiának.

A fejlődô, felzárkózó országok ritkábban foglalkoznak csúcstechnikával. Eltekintünk itt azoktól a nagyhatalmaktól (például Kína), amelyek ugyan (még) nem tartoznak a legfejlettebb országok közé, de világhatalmi szerepük megkérdójelezhetetlen. (És nem gondolunk most Észak-Koreára sem.) Azonban másutt is gyakran - és szükségtelenül - az egyszerúbb termékek elôállítására is a legmodernebb eszközöket használják (még abban az esetben is, amikor a munkabér olcsó lenne).

Mi az oka? Mert a gép például nem sztrájkol... A gép relatíve olcsóbb. (A relatív olcsóság persze viszonylagos fogalom.) Az élômunkának ugyanis, a gépköltségekkel szemben, vannak pótlólagos bérarányos terhei, amelyek megnövelik a bérjellegú kiadásokat. Emellett szükség lehet szociális beruházásokra, juttatásokra is. Mindez megemeli a bér súlyát a költségekben. Ezért sokszor gazdaságosabb géppel kiváltani az élômunkát. A hitel napjainkban olyan bôségben áll rendelkezésre, hogy a gépi megoldás megelólegezése vállalati szinten olcsóbb. A vállalkozót pedig általában cseppet sem érdeklik az alkalmazott technológia társadalmi következményei. A maximális profitabilitás igénye mellett a tôkében gazdag vállalatoknak nem éri meg az élômunka foglalkoztatása, ha annak kiküszöbölésével nagyobb profitot tudnak realizálni, például a skálahozadék érvényesítésével.

Az emberi munka értelemszerúen nem tud olyan termelékenységet, idôegységre jutó termékmennyiséget felmutatni, mint a gép. Ilyenkor nem várhatjuk - pontosabban: hiába várjuk - a magántôkétôl, hogy gondoskodjék az emberek megélhetését jelentô foglalkoztatásról. Közösségi szinten azonban a társadalompolitika és a gazdaságpolitika makroszempontjainak elôtérbe kellene kerülniük!

Makroszinten átlagos gazdasági növekedés akkor is kimutatható, ha csak néhány nagyvállalat profitja nô. Ez elaltatja a gazdaságpolitikusok figyelmét, akik többnyire 
csak az összevont adatokat nézik. Úgy látják, a GDP növekedést jelez, tehát minden rendben van! Ettől azonban az ország lakossága még nyomoroghat. Egy közösségi szemléletû - tehát nem csak egy vékony társadalmi réteg (mindenekeloott a leggazdagabbak) érdekeire figyelô - gazdaságpolitika számára nem lehet mindegy, hogy ugyanazt az eredményt milyen munka-tóke arány mellett lehet elérni. Hibát követünk el, ha csak a GDP-adat növekedését figyeljük. A GDP, amely a bér és profit együttese, a tôkének, méghozzá a nemzetközi tôkének kedvelt mércéje (no meg a nemzetközi intézményeké, amelyek ezek szerint csak a tôke szempontjait figyelik, pedig a tagországaik közpolgárainak jólétét is fontosnak kellene tartaniuk).

Arra, hogy a GDP nem jó mérôszám, már az IMF kutatói is rádöbbentek (Stiglitz, 2016a). Mégis, érdemes elidőzni a közelmúltbeli tényezôár-alakulás történeténél. A termelés fố tényezôii, a munka és a tôke relatív áralakulását illetôen Raghuram Rajan, a chicagói egyetemi tanár, az IMF volt fôközgazdásza, az indiai jegybank volt elnöke már korábban rámutatott, hogy az USA-ban a kamatok minimálisra csökkentésével eltorzultak a tényezôárak (Rajan, 2010), hiszen így nagyon olcsóvá vált az a technológia, amely az élőmunkát kiváltja. Rajan szerint ez olyan növekedéshez vezetett, amely nem jár a foglalkoztatottság emelkedésével (Rajan, 2010; Martus, 2016). Amikor a munkanélküliség számos országban igen magas, ez a jelenség egyáltalán nem kívánatos. Még az USA-ban sem, hiszen bár ott nem magas a munkanélküliség átlagos adata, de az alacsonyabb képzettségúek munkája iránti kereslet erôsen csökkent. Sơt, ma már a felsô szinten képzett, új munkát keresôk is nehezen tudnak elhelyezkedni (Reich, 1992). Ez pedig oda vezetett, hogy az amerikai átlagbér lassan negyedszázada nem emelkedik, noha a GDP növekszik. Akkor mégis mi növekedett? A (bér+profitból) a profit növekedett, ugyebár. Mondhatjuk-e, hogy a GDP mutatója az egész gazdaság és társadalom helyzetét (érdekét) kifejezi? Nyilvánvalóan nem. A béremelkedés elmaradása számos területen visszafogja a gazdasági növekedést, hiszen visszafogja a kereslet növekedését is.

Ami hazánkat illeti, az elmúlt negyedszázadban viszonylag olcsó volt a munkaeró, mégsem érvényesült olyan gazdaságpolitika, amely ennek kihasználásával - adekvát technológia alkalmazásával - kísérelte volna meg a társadalom szükségleteit kielégíteni. Nem olyan technikával megvalósuló beruházásokra került sor, amelyek fố célja a foglalkoztatás lett volna. A gazdaságpolitikát ugyanis éveken át a külföldi (múködô) tôke beáramlása irányította, amelyet nem feltétlenül érdekeltek a makrogazdasági következmények. A beáramlásban fontos szempont volt az olcsó bér, ezt azonban tôkeigényes technológiával párosították. (Egy bô tíz évvel korábbi felmérés [Botos-Botos, 2014] azt mutatta, hogy hazánkban az EU-csatlakozás idején a termelôeszköz körülbelül felefele arányban volt hazai, illetve külföldi tulajdonban. A foglalkoztatottságnak azonban csak 20\%-át biztosították a külföldi tôkével múködô cégek, tehát a hazai tôke foglalkoztatta a munkavállalók 80\%-át.) A külföldi tôkétôl aligha várhatjuk a foglalkoztatási problémák országos megoldását. A rendszerváltozás óta fokozódó globalizáció még kevesebb esélyt adott az adekvát technológiával múködô cégek érvényesülésének. A távol-keleti importdömping alávágott a hazai termelésnek.

Mire is szolgált a privatizáció kapcsán hazánkba áramló, illetve az azóta zöldmezôs beruházásként megvalósuló (vagy visszaforgatott) külfölditóke-befektetés? A makro- 
és mikrogazdasági szempontok furcsa egybeesését tapasztalhatjuk a tókebeáramlás folyamatában. A rendszerváltásig döntôen kölcsöntôke áramlott be, azt követôen termelőtôke is. Devizára égetô szükségünk volt a külsố adósságunk csökkentése céljából. (A gazdaságpolitika egyik legfőbb rendezôelve szinte mindig - de a rendszerváltozás kezdeti szakaszában különösen - az volt, hogy biztosítsuk a minél nagyobb mértékú külfölditôke-beáramlást.) Ez azonban figyelmen kívül hagyta a foglalkoztatáspolitika szempontjait.

1990 után a külföldi tôke mindenekelôtt az olcsón megszerezhetô privatizációs javak miatt jött hazánkba. Ezen belül is elsôsorban a nem túlzottan munkaigényes infrastrukturális szolgáltatások területére áramlott (gáz-, víz-, áramszolgáltatás). Ezek viszont biztos hazai piacot jelentettek (Botos-Botos, 2014). (Olykor az egyéb területekre bejövố privatizációs tôke piacot vett meg. Megszüntette a hazai termelést, így teret szerezve saját termékei exportja számára, lásd cukoripar.)

Késôbb, a 2000-es években s különösen az Orbán-kormányok idején megvalósuló reindusztrializáció nyomán már látszottak kormányzati törekvések a foglalkoztatáspolitika javítására. Sajnos azonban bár a bejövô tôke a viszonylag alacsony bérszínvonalat figyelembe vette, ezt azonban továbbra is az egyébként magas szintú technikával párosította. Így nagy termelékenységgel, ugyanakkor alacsony bérköltségekkel termelt. Nyilvánvalóan az eddigi üzletpolitika egy exportorientált iparpolitika megvalósulásához vezet. Az autógyártás fơ piaca például nem a viszonylag szúk magyar felvevoópiac, hanem a külföldi piacok. (Egyébként, más országokkal összehasonlítva, fajlagosan meglehetôsen magas a magyar autótulajdonlás.) Ma már ezeknél az autóipari létesítményeknél - Győr, Kecskemét - az elmúlt évtizedekben elhanyagolt szakmai képzések következtében bizonyos munkaeróhiány is tapasztalható, amely legalább valamelyes béremelésre ösztönöz. (Csak napjainkban hallunk híreket arról, hogy egyes külföldi cégek magasabb képzettséget igénylô munkafázisokat is idetelepítenek majd.)

Azok a hazai (adekvát tôkét igénylő) vállalkozások azonban, amelyek a magyar piac számtalan szükségletének kielégítésére képesek lennének, és termelésükkel szélesebb körú foglalkoztatást tudnának biztosítani, egyszerúen versenyképtelenek a beáramló importtal szemben. Alig van lehetôség az olcsó távol-keleti - de akár európai - egyszerúbb termékek kiváltására, ezeknek a termékeknek a hazai elôállítására a még meglévô - az adekvát technológiához alkalmas - munkaeróbázisunkon. A belföldi piacot letarolja az import. Szóban szinte valamennyi kormány zászlajára túzte a hazai kisvállalkozások segítését, ez azonban - jó esetben - inkább csak a forráshoz jutás terén tudott megvalósulni. Napjainkban is igyekszik a kormányzat olcsó forráshoz juttatni a kisvállalkozókat. Vajon miért szerények az eredmények? Hiába visszük a vödröt a lóhoz, ha nem akar inni: ha nem eléggé ígéretes a felvevôpiac, amire egy beruházást alapozni lehetne, akkor kevesen élnek a lehetôséggel.

Nem eléggé hatékony tehát a kisvállalkozásokat támogató politikánk. Még mindig valami homályos, absztrakt „piac” fogalomrendszerében fogalmazódik meg. Márpedig a globalizmus korában „a piac” versenye - ami gyakorlatilag mindig nemzetközi verseny - ellehetetleníti a kevéssé tôkeerôs hazai megoldásokat. Az adekvát technológiát alkalmazó, kis- és közepes vállalkozások segítéséhez tehát rendkívül fontos lenne 
a lokális piacok garantálása. Enélkül a globális verseny, a beözönlô import minden hazai erőfeszítést elsöpör. Olyan olcsón gyártott termékeket hoznak be, amelyeket még a mi béreinkhez képest is alacsonyabb élőmunkaköltséggel s ugyanakkor olyan fejlett technológiával állítottak elő, hogy azokkal a magyar kisvállalkozók nem tudnak versenyezni. A távol-keleti cégek a sorozatgyártással olyan hatalmas elónyt biztosítanak a saját maguk számára, hogy az a nagy távolságra történô szállítási költségeket is lenullázza. Ha kell, ezek a tôkeerôs kereskedôcégek átmeneti áldozatokat is tudnak vállalni a piacra való betörés érdekében. Ámbár, az ázsiai vállalkozók fajlagos folyó költségei annyira alacsonyak, hogy a dömpingvádat se teszik ellenük felhozhatóvá. Hogy ez az ó gazdaságuk foglalkoztatáspolitikája szempontjából mennyire hasznos, az kérdéses. De tény, hogy pl. Kína százmilliókat emelt ki a mélyszegénységból, így ók a maguk részérôl minden bizonnyal sikeresnek értékelik ezt az iparpolitikát.

De Kína sem a hazai piacra termel elsôdlegesen: hatalmas exportpotenciálok épültek ki az ázsiai tengerparti övezetekben. Úgy is fogalmazhatunk, hogy Ázsiából milliárdos munkaeró-kinálat kapcsolódott be a világpiacba. Ez a fejlettebb országok béreit leszorítja. S bizony, ez ránk is érvényes: a mi béreink még fölötte vannak az ázsiai színvonalnak. Mivel az Ázsiából behozott termékeket ugyanakkor magas technikával, nagy sorozatban gyártják, a béren kívüli költségeik is alacsonyabbak. Ezért tarol az import, és ezért csökken például még a hagyományos magyar vöröshagyma, fokhagyma termésterülete is, hiszen a termelók nem tudnak versenyezni a kínai behozatallal.

De más területek termékeire is igaz ez. A borpiacot csaknem teljesen tönkreteszi a beáramló, rendkívül olcsó behozatal. Teljességgel érthetetlen például, hogy az egyszerú szerszámok, mezőgazdasági eszközök előállítását is ellehetetleníti a finn import. Pedig ezek előállításához nincs szükség olyan szakértelemre, amellyel ne rendelkeznénk itthon, és a béreink minden bizonnyal kisebbek a nyugat-európainál. Mégis alig van hazai gyártás a fenti termékekból. A gazdaságos termeléshez elégséges piac lenne az ország határain belül is. Nehezen érthetô tehát - elsôsorban a tôkehiánnyal magyarázzák -, hogy miért nincs erre mégsem hazai vállalkozó, miért nyugat-európai importot hozunk be ezekból a termékekból. Nyilván a menedzsment-, marketing-, piacszervezési ismeretek szintje is akadályt jelent. Viszont az, hogy két és fél évtized kevés volt ezen ismeretek pótlásához, igencsak elgondolkodtató.

Joggal vetôdhet fel, hogy ezek a protekcionizmusra utaló gondolatok retrográdak. Azonban nem a mindenáron való importhelyettesités protekcionista elvét látszik szükségesnek hazai viszonyainkban érvényre juttatni, csupán az adekvát technológiáét.

A magyar kormányzatok, amint ezt tapasztalhattuk az elmúlt évtizedekben, az élómunka terheinek folyamatos csökkentésével próbáltak segíteni a hazai vállalkozások versenyképességének növelésében. (Más kelet-európai országokban is ezt az utat követték. Mindenki az alacsony bérszínvonallal kívánt versenyképes maradni.) Béreink ugyan - mint utaltunk rá - alacsonyabbak voltak, és még mindig azok maradtak a nyugat-európai színvonalhoz képest, de mégsem csökkentek le az ázsiai szintre. A bérterheket (járulékokat, adókat) viszont a kormányzatok erôteljesen csökkentették.

A járulékmérséklést azonban a kormányzat a jövó számlájára teszi. A tb-járulékok általános csökkentése kellemes ajándékot jelent a multicégeknek, amelyeknek az 
európai bérköltségekhez képest igy is olcsók voltunk. Igaz, kétségtelenül könnyebbséget jelentett a kisebb hazai vállalkozók számára, amelyek egyébként a foglalkoztatás nagyobb részének terhét viselik, és már mindenképpen versenyképességük határán vannak. (A folyamatos minimálbér-emelés is nagy kihívás számukra.) És ami érdekes, maguk a munkavállalók is az olyan foglalkoztatási formákat preferálják, amelynek adóterhe (járulékterhe) alacsonyabb. Hisz így valamivel több elkölthetô pénzük marad.

De mindez annak az árán történt, hogy a nagy elosztórendszerekben halmozódnak a feszültségek. Az egészségügynek már most kevés az egészségbiztosítási alapból származó (bérarányos) forrása. A munkaképes korosztály demográfiai csökkenése miatt az alacsonyra levitt járulékszint (amely most a szociális hozzájárulási adót is jelenti) kevés államháztartási bevételt hoz majd. A nyugdíjrendszer nem tud tartalékot képezni a járulékfizetôk számában 2030 körül várható hirtelen és határozott demográfiai visszaesésre. A munkavállalók jelenlegi előnyösebb bérösszegekhez jutása azt jelenti, hogy néhány évtized múlva viszont csak igen csekély nyugdíjjal számolhatnak. Egyre jobban kirajzolódik a fenyegetô jövókép, melynek eredménye a várhatóan nagyon alacsony átlagnyugdíj-színvonal lesz. Az idôskori szegénység beköszöntése vár ránk. Elgondolkodtató, hogy az emberek ezzel valójában nemigen törôdnek; növekedett ugyan a nyugdíjcélú megtakarítások volumene, de a probléma komolyságát nem érzékelik. Majdcsak lesz valahogy: a politikának szüksége van a nyugdíjas szavazókra, majd kitalálnak valamit.

A kormányzat a jövedelem adóterheit is mérsékelte az elmúlt években, amely segítség volt a bérból élôknek, és valóban némi fogyasztásnövekedést hozott. Sajnos azonban ezt nálunk jól megcsapolta a devizahiteles csốd, ami elvitte a szegényebbek minden fölös fillérjét (s volt, ahol a nem fölöset is).

A bérköltségek „versenyképesebbé tétele” csak megerôsítette (az egyébként is alapvetôen) a bérkülönbségen alapuló külfölditơke-beáramlást. Olyan fejlesztô állam koncepció kellene, amely elképzelhetôvé teszi, sôt, eredményezi az érdemibb munkafázisok hazánkba telepítését. A kormányzat már felismerte az alacsony bérek problémáját. Ebben az elvándorlás miatti munkaerôhiány is szerepet játszott. Ez azonban sokkal részletesebb gazdaságpolitikai ösztönzórendszer kidolgozását kívánja meg, mint a „majd a piac" elvére alapozó laissez passer magatartás, amely a korábbi idószakot jellemezte. Nyilván nem lehet szorgalmazni a befektetéseket, ha nem áll rendelkezésre a magasabb szintû munka végzésére alkalmas munkaerô. Ami azt jelenti, hogy az államnak az oktatásra fordított beruházások és folyó finanszírozás emelését is el kell érnie, vagyis be kell fektetnie a jövóbe! (Ami viszont az elmúlt években a válság megszorításai miatt éppen elmaradt.)

\section{A JÖVEDELEMEGYENLŐTLENSÉGEK FOKOZÓDÁSA}

Az elôzôhöz kapcsolódó téma a jövedelmi és vagyoni egyenlôtlenségek fokozódása. Ez a trend mind a világban, mind nálunk tapasztalható. Elkerülhetetlen törvényszerúségrôl van szó? Mi a jelenség oka? A kérdést elsôsorban a „zászlóshajó” tapasztalatai alapján vizsgáljuk. 
Joseph Stiglitz két utóbbi könyvében (Stiglitz, 2013; 2016a) sokoldalúan mutatta be, hogy az a gazdaságideológia, amely uralkodóvá vált az USA-ban a Reagan-korszak után, társadalmi méretekben kudarchoz vezetett. Természetesen akkor, ha a társadalom céljának az erôs középosztály kialakulását tekintjük. Sôt ez a cél nemhogy nem valósult meg, de egyenesen romlott a középosztály helyzete. Stiglitz rámutatott, hogy a 99\% jövedelmi helyzete rosszabbodott, míg az 1\% helyzetének kiugró javulása következett be. Ez jelentôs részben az USA adórendszerének következménye. Az átlag amerikaiak vagyoni helyzete 2014-ben 40\%-kal rosszabb, mint negyedszázaddal korábban, miközben a GDP növekedett. Mi az oka annak, hogy az átlag amerikai helyzete egzisztenciálisan sokkal bizonytalanabb, mint három évtizede volt?

A „hagyjuk a pénzt a polgárok zsebében” elv, amivel Amerikában Reagan és a republikánusok az adócsökkentések mellett érveltek, leginkább a gazdagabbak adóterhein könnyített. Stiglitz bemutatta, hogy fajlagosan mennyivel kisebb jövedelemadó-terhet viselnek Amerikában az 1\% tagjai, mint a 99\%-ba tartozók (Stiglitz, 2013; 2016a). A vállalatok adóteher-viselés alóli kibújása gyakorlati problémát jelent. (Ez egyébként a magyar adórendszerben is létezó gond.)

Ha az alacsonyabb jövedelmú társadalmi rétegeknél nem nô a reálkereslet, akkor egészen biztosan lassan bôvülhet a hazai fogyasztási piac is. Ilyen esetben csak az exportorientált iparfejlesztés a kiút, amelyet a (liberális) gazdaságpolitika a rendszerváltás előtt és után is folyamatosan szorgalmazott nálunk is.

Gondolkodjunk el egy kicsit hazai viszonyainkon. Joggal vetôdik fel a kérdés: miért nem emelkedett érdemben az átlagbér a közelmúltig? Azért, mert a beáramló külföldi tôke legfeljebb a bérszempontból gazdaságos, egyszerúbb összeszerelô munkákat profilírozta ránk. Mint fentebb láttuk, az érdemi munkafázisokat nem „exportálja”. A fejlesztést, irányítást, a jobban fizetố munkahelyeket a külföldi cég menedzserei megtartják maguknak és anyaországi munkatársaiknak. Robert Reich az amerikai gazdaságot vizsgálva már jó negyedszázada kimutatta, hogy egy ország gazdagsága, fejlettsége, fajlagos GDP-je nem attól függ, hogy hazai vagy külföldi tôketulajdonos van-e jelen, hanem elsôsorban attól, hogy mennyi jól fizetett hazai munkatársat alkalmaz a hazai gazdaságban a múködő vállalkozás (Reich, 1992). A gazdaság fejlettségi szintjének emelkedését a kvalifikált, nemzetközileg is versenyképes munkát ellátni képes emberek alkalmazása eredményezheti, függetlenül attól, milyen nemzetiségú a tôke tulajdonosa. Az össztársadalmi jólét növekedése az alkalmazott munkaerô minôségétől és annak honorálásától függ. Hiszen bérük elvileg ennek függvénye!

Ismert tény, hogy a fejlett világban a GDP összetételében a bérjellegú elem nagysága döntô. A bér- és tôkejövedelem hányada egyaránt fele-fele, de inkább a bér javára van eltolódás. Nálunk ez éppen fordítva van, 40-60\% az arány, a bér hátrányára. Árulkodó adat ez a mikrogazdasági szinten versenyképessé tevô bérek makrogazdasági hatásáról! Továbbá: mi azon néhány ország közé tartoztunk, ahol a GNP alacsonyabb, mint a GDP. Vagyis a külföldi tulajdonosok az itt termelt profit jelentôs részét hazautalják. Ezt nem kompenzálja a visszautalt profit, mert a kiáramló magyar tôkebefektetés sokkal kisebb volumenú, mint a beáramló külföldi tôke. A mi GDP-nk emelkedése tehát nem az itt élook jövedelmének növekedését jelenti, hanem - döntô hányadban - a profit nö- 
vekedését, méghozzá a külföldi kézben lévô vállalkozásoknál, amiből maga az ország (bérben, adóban) viszonylag kevéssé részesedik. Kevés foglalkoztatásbôvítést jelent a vállalkozásoknál maradó profit, akkor is, ha viszonylag számottevô az újrabefektetés. Alacsonyak a társasági adók, sok a vállalatok anyavállalati hitele, aminek kamatterhe ismét csak nem adózás alá esố tétel az itt lévố multinacionális vállalatok számára, hanem költség. Vagyis az állam sem részesedik megfelelôen az itt termelt jövedelmekból, még ha a költségvetésbe befizetett adók nagyobb hányada ered is a külföldi tulajdonú cégektôl. Ez csak azt mutatja, hogy a magyar tôketulajdonosok jövedelmezôsége igen alacsony, nincs mibôl adózniuk. A magyar jövedelemosztozkodás rendszere tehát nálunk is gátja a hazai piac bôvülésén alapuló gazdaságnövekedésnek.

Valójában ezzel már érintettük a harmadik témakört is. Ez pedig a jelenlegi nemzetközi pénzügyi rendszer.

\section{BRETTON WOODS: VISSZA A GYÖKEREKHEZ?}

Gondolkodásunk kiindulópontja Dani Rodrik könyve, A globalizáció paradoxona (Rodrik, 2015). A mú világosan bemutatja, hogy a Bretton Woods-i pénzrendszer olyan változásokon ment keresztül, amelyek nem egyformán elönyösek valamennyi résztvevô számára, hanem valójában a nemzetközi jövedelempolarizációt szolgálják. A statisztika ugyan azt jelzi, hogy a fejlődő, felzárkózó országok a globalizmus haszonélvezôi voltak (lásd Kína), hiszen az egy fốre jutó GDP jelentôsen nôtt ezekben a gazdaságokban. Sốt egyesekben sokkal nagyobb ütemben emelkedett, mint a fejlett gazdaságokban.

Ez a tény azonban jól megfér azzal az állítással, hogy a globalizmus szabad tókeáramlása rendkívül sebezhetố helyzetbe hozott számtalan országot. Fejlettekben és fejlődőekben egyaránt rengetegen veszítik el a munkalehetôségeiket. A külföldi import a fejlett országokban is letarolja a piacokat. A fejlődó országokban sok esetben a nem adekvát technológiát alkalmazó tôkebeáramlás rontja a hazai termelôk foglalkoztatási lehetôségeit. Egyes területek valóban fejlôdnek bizonyos felzárkózó országokon belül, s ezekben a beáramló tóke kétségtelenül teremt is számos munkahelyet, de máshol gyakran többet szüntet meg. Miért? Mert az adott fejlôdô országban, ahová a tôke áramlik, a bevitt korszerú technológia valójában kevés munkást alkalmazó jellegú (azaz igen korszerú, korábbi fogalmaink szerint nem adekvát technológiájú), a fejlett országokban viszont, ahonnan a termelést elviszik, és ahová a fejlôdô országokban rendkívül olcsón termelt termékmennyiség beáramlik, megszúnnek a munkahelyek, vagy csökkennek a bérek az importverseny miatt.

A globalizmus elkötelezett hívei azt hirdetik, hogy a szabadkereskedelem és tókeáramlás világméretekben összességében elônyös. Állítják, hogy nem a globalizmus változtatta meg a bérviszonyokat, hanem maga a technológiai haladás, amely egyértelmúen leértékeli a nem képzett munkaerôt. Arra van szükség, mondják, hogy a fejlett országokban a munkaerô gyors és megfelelő képzéssel alkalmazkodjék az új világgazdasági kihívásokhoz. Arra viszont nem utalnak, hogy éppen ez nem megy olyan ütemben, mint kellene. (Ahogy arra sem, hogy miért; például az oktatási költségek drágulására.) 
Meglehet tehát, hogy valóban a technikai haladás a bértorzulások oka, de vitathatatlan, hogy ezt a hatást erôsíti a szabad tôkemozgás.

Rodrik világosan megfogalmazza, hogy amíg a globalizáció korábbi szakaszaiban a tôkeáramlások korlátozásával tudott egy fejlôdô ország valamelyest önálló gazdaságpolitikát folytatni, a jelen pénzügyi mechanizmus ettôl a lehetôségtôl megfosztotta óket. Ez sok országot nyomorba taszít. (Persze nem szabad elfelejteni, hogy a nyomorban a népességrobbanásnak is jelentôs szerepe van.) Állítása szerint a modern világ egy sajátos trilemmával néz szembe. A nemzetközi piacok és a nemzeti keretekben múködô demokráciák között ellentmondás feszül. Nem lehet egyszerre akarni a hiperglobalizációt, a demokráciát és a nemzeti szuverenitást. A három cél egyszerre nem valósulhat meg, közülük legfeljebb csak kettô.

A trilemmát három módon oldhatjuk fel:

- korlátozzuk a nemzeti keretek között múködó demokráciát, hogy minimalizáljuk a tranzakciós költségeket, és figyelmen kívül hagyjuk, hogy a nemzetközi folyamatok idônként társadalmi feszültségeket okoznak az országban; vagy

- korlátozhatjuk a globalizációt, biztosítva ezzel a hazai demokrácia kiteljesedését; vagy

- globalizálhatjuk a demokráciát, amivel azonban korlátozzuk a nemzeti szuverenitást. Ez a nemzetközi kapcsolatok olyan fejlesztését jelenti, ami egyfajta demokratikus alapon múködő világállam felé mutat (erre még nem látszik érettnek a világ).

Valamennyi célt egyidejûleg bizonyosan nem tudjuk elérni. Thomas Friedman amerikai zsurnaliszta úgy fogalmazott: a globalizáció korában az országoknak „aranyból szótt kényszerzubbonyt” kell hordaniuk (Rodrik, 2015:255), hogy a hazai pénzügyi helyzetet olyan vonzó egyensúlyban tartsák, amely „tetszik” a nemzetközi tôkepiacok szereplóinek. E szerint azonban a kormányok nem szuverének! Az a feladatuk, hogy a feltételeket megteremtsék, amelyek mellett biztosított a külföldi tôke érdekeltsége a gazdaságban. Tehát alárendeltek a külföldi tôke céljainak. Ha ennek az ára a szigorú szükségállapot rákényszerítése az országra - mint pl. egyes országoknál az eurózóna jelenlegi válságos helyzetében -, akkor aligha beszélhetünk globális demokráciáról. De semmiképp sem beszélhetünk teljes nemzeti szuverenitásról. A hiperglobalizáció érvényesüléséhez - Rodrik kifejezésével élve - szükség volna a „belpolitika kiszorítására” (Rodrik, 2015:256). A jegybankok, pénzügyi hatóságok elszigetelődnek, a társadalombiztosítás eltúnik vagy privatizálódik, az adórendszer változtatása az adócsökkentésekért folytatott lobbi következtében változik, alakul (Rodrik, 2015; Stiglitz, 2016a). A munkaadók és munkavállalók közötti kohézió csökken (Dardot-Laval, 2013). A hazai befektetési célokat a befektetôi bizalom fenntartásának kötelezettsége váltja fel. Így a hosszú távú infrastrukturális beruházások kiszorulnak az államháztartás kereteibôl (Truger, 2015). A fentebbi felsorolást azért adatoltam szinte mondatonként, mert ezek a gondolatok nem egy-két szerzót jellemeznek. Mindenesetre komplexebben közelítik meg a kérdést, mint a globalizmus szabad tókeáramlását feltétel nélkül elfogadó szakértôk.

Rodrik úgy véli, a globális föderatív politika lehetne az, ami zöld utat biztosítana a globalizáció világméretú kiteljesedése demokratikus megoldásának. Ez valójában nem 
más, mint az amerikai állam rendszere, csak globális szinten. Létrejöttét várni azonban a jelen politikai helyzetben s annak belátható idôn belüli alakulásában nem reális. A nemzeti szuverenitások korlátozásának fentebb leírt gyakorlata a társadalmi feszültségek olyan súlyosbodását eredményezheti, amely robbanáshoz vezethet. A másik lehetôség, a demokrácia feladása pedig társadalmi szempontból semmiképp sem kívánatos (még akkor sem, ha Kína autoriter állama szemmel láthatólag megfér valahogy a piacgazdasággal, és polgárai jó részének jelentős életszínvonal-javulást hozott). Mert demokrácia híján mi garantálná, hogy nem kerül-e hatalomra egy másfajta autoriter vezetés, amely - mint Észak-Koreában - az emberek nyomora árán is képes fantaszta céljait keresztülvinni? Az elmúlt hetven évben e téren volt kellő tapasztalat a világban, és itt, Kelet-Közép-Európában. Most már csak az a kérdés maradt, hogy a demokrácia képes lesz-e, és hol, egy ilyen fejleményt megakadályozni. Alapvetô ideológiai-kulturális, sốt bizonyos mértékig vallási alapok nélkül valóban nincs rá biztosíték. (Ezt mutatják napjaink világméretú történései, fóképp az arab világban.) De ha így van, akkor az egyetlen reális gazdasági alternatíva a globalizáció bizonyos korlátozása marad. Rodrik szerint erre szükség is van.

Mellesleg, Kína az eddig követett monetáris politikájával - az export ösztönzése érdekében alulértékelten tartott jüannal - valójában egyfajta védelmet biztosított a maga számára, kihasználva a nemzetközi szervezetek szabályozásában lehetséges kiskapukat és azt a sajátos körülményt, hogy a pénzhigítás a rendkívül magas kínai megtakarítási hajlandóság miatt nem okozott jelentős, korrekcióra kényszerítô inflációt az országban. Legalábbis eddig. Tegyük hozzá, hogy nemzetközi finanszírozási tevékenységében, amit ez a politika lehetôvé tett a hatalmas devizatartalékokkal, az Egyesült Államok is érdekelt volt, hiszen az amerikai deficitet és államadósságot finanszírozta.

Rodrik javaslatának értelmében a nemzetközi pénzügyekben vissza kellene állni a második világháború utáni elsố negyedszázad nemzetközi pénzügyi rendszerének gyakorlatára. Bretton Woods garantálta a nemzetközi kereskedelmi és fizetési forgalom szabadságát, de a tôkemozgások terén megengedett bizonyos korlátozásokat. Védekezési mechanizmusok nélkül ugyanis a szabad verseny olyan, mint a sánták és olimpikonok mérkôzése, amelyben a vesztesek kódolva vannak. Ma már maga az IMF egyes szakértôi is elismerik, hogy a szükségállapotok fundamentalista politikája - amit Stiglitz valamiféle „hooveri megoldásnak” nevez - nem járható út (Stiglitz, 2016b). (Hoover amerikai elnök szigorú megszorításos politikája volt az utolsó csepp a pohárban, amely az 1929-ben kirobbant nagy világválsághoz vezetett.) S ha figyelembe vesszük, hogy ma az európai perifériaországokban a munkanélküliség mértéke eléri, sôt meghaladja a 1929-1933-as válság adatait, el kell gondolkodni e hasonlóságon. Akkor is összeomlott az aranystandard, és hatalmas gazdasági visszaesés következett be. Hogy ez mennyiben készítette elố a tragikus második világháborút, nehéz lenne megmondani, de aligha lehet vitatni az összefüggést. És most ezeket a megszorításokat erôltetjük Európában (és számos fejlôdô országban is)? Mindenesetre az Egyesült Államok a maga részérôl az állami eladósodást, a szabályozások szigorítását, tehát a határozott állami beavatkozást választotta. (Hogy ezt hogyan, milyen alapon tehette meg úgy, ahogy megtette, arra most nem térünk ki.) 


\section{A FINANGIALIZÁGIÓ}

Negyedikként idézzük fel a pénzügyek általános kérdéskörét. Számos lejárt szavatosságú törvényszerúségre fogunk itt is találni. Nézzük elôször a monetáris politikát!

Évtizedek nemzedékei tanulták úgy, hogy a pénzteremtést a jegybankok szabályozzák a monetáris politika eszköztárával. A pénzügyi szektor pedig nem egyéb, mint a gazdaság hatékonyabb múködésének szolgálatában álló, pénzközvetító intézmény, amelyet megfelelő szabályozások tartanak kordában. Pénzt valójában csak a jegybank teremt, s ezt a kereskedelmi bankok multiplikálják. Így tanultuk és tanítottuk.

Mindez napjainkra elavulttá vált. A jegybank természetesen valóban teremt pénzt (lásd a kínai politikát), de ma már elfogadott, hogy a kereskedelmi bankszektor is önállóan teremt pénzt. A jegybank pedig nem meghatározza ezt, hanem többnyire csak utánamegy a folyamatoknak a szabályozással. A tartalékráta mint pénzmultiplikátor elvesztette érdemi pénzmennyiség-szabályozó hatását. (Már csak azért is, mert számos helyen nulla vagy annak közelében van.) Nem kell a jegybankpénzt multiplikálni, van belóle elég a rendszerben...

A gazdaság növekedését tehát a pénzügyi intézmények pénzteremtô döntései befolyásolják. Mitôl függenek ezek? A bankszektort szinte kizárólag a profittermelés szempontjai vezérlik, nem a reálgazdaság szolgálata. Ez alapvetô változás a korábbi idôkhöz képest. Mindig is a profittermelés volt a bankipar célja, de nem mindegy, hogy minek a révén. Amíg a szükségletek ugrásszerú bôvülése következtében kínálkozó piacok kielégítéséhez nem lehetett eleget termelni, addig számos reálberuházási lehetôség kínálkozott. Most azonban a (fizetôképes) kereslet telítetté vált. A banki szektor mindent megtesz, hogy felkutasson befektetésre, tehát finanszírozásra alkalmas területeket. Mivel azonban, mint az eloozố pontokban láttuk, a bérbôl élook jövedelme nem bôvül arányosan, így a reálberuházások helyett gyakran a spekuláció felé fordul. Ezért még mindig jobb egy olyan értékpapír megvásárlása - akár felárral is -, amely egy dinamikus fejlódést ígérô cég papírja, mint a megkeresett és megtakarított jövedelmeket parlagon hagyni. (A folyószámlán lévô pénz ugyanis nem hoz semmit, s napjainkban a betétszámlán is keveset.) Az ilyen értékpapír-kereslet azonban felhajtja a dinamikus ágazatok értékpapírjainak árát. Erre a pénzügyi szektor hitelfinanszírozással rá is játszik, adott esetben hitelnyújtással segíti. (Már 1929 elốtt is ez volt az egyik probléma.) Megfelelố szabályozás híján sorozatosan alakulnak ki a pénzpiaci buborékok (lásd a 2000-es években a dotkomválságot, majd 2007 után a jelzálogpiaci válságot). A reálberuházások növelésére csak úgy van lehetôség, ha:

- a lakosság többet fogyaszt, mint amennyit keres, gyakorlatilag hitelbôl, vagyis a jövőbeli jövedelmét előrehozza, annak terhére fogyaszt. Így lehetôséget ad a tôkének a termelésbôvítésre, kapacitások kihasználására, további profitrealizálásra; illetve

- ha olyan szükségleteket sikerül generálni, amelyek a lakosság számára vagyonfelhalmozást jelentenek, hitelbôl. Ilyen a jelzáloghitelre történô ingatlanvásárlás.

A nettó vagyon természetesen csak a hitel törlesztésének mértékében nô. A törlesztési késedelembe esô, törleszteni képtelen fél azonban a jelzálog miatt elveszítheti még a hitel saját részeként befizetett megtakarítását is. A jelzálog-finanszírozásnál a 
pénzügyi szektor éppúgy a jövơbeni jövedelmeket terheli le a nyújtott hitelekkel, mint a fogyasztási hiteleknél, méghozzá a fogyasztási hiteleknél jóval hosszabb idôtartamra. Mivel nagyon jelentôs összegeket hiteleznek meg, éppen ezért kötik ki az ingatlanra a jelzálogot. Feltételezik, hogy a jövedelemból lesz olyan rendszeres megtakarítási hányad, amely a hitel törlesztésével vagyonképzést szolgálhat. A csáberô itt az, hogy a lakásba nyomban be lehet költözni, s ez a tulajdon érzetét kelti, és a törlesztés ténylegesen kiváltja a lakásbérlet költségeit. A bank azután e jelzálogokkal fedezett hiteleket értékpapírosítva, a maga részérôl további kihelyezhetô forráshoz jutott, az amerikai gyakorlat szerint. Pontosabban, mérlege az értékpapírosított hitelek értékesítéséból származó készpénzaktívákkal egyensúlyban lesz, és megnyílik előtte a további jövedelmezô pénzteremtési lehetôség útja.

Miból nyújtják a bankok ezeket a hiteleket? Láthatjuk: pénzteremtésból. A bankok a hitel nyújtásával egyidejúleg teremtenek pénzt, mérlegük két oldalát megemelve: itt a hitel, aktíva mint követelés, ott a betét, a bankpasszíva, ami a teremtett pénz számlára történó jóváírásából ered. Ami tehát a bank kötelezettségét jelenti a hiteligényló felé. Ez ugyan csak kereskedelmi banki pénz, de nem gond jegybankpénzzé alakítani. A bankok ugyanis helyt tudnak állni a finanszírozás jegybankpénzigényét tekintve, hiszen a gazdaságban már meglévố jelentôs pénzügyi megtakarítások a rendelkezésükre állnak, akár saját maguknál lévô betétállományok, akár más pénzintézettôl való kölcsönök útján. És a jegybank, ha kell, gyakorlatilag utánamegy jegybankpénzteremtéssel a meghozott kereskedelmi banki döntéseknek, megteremti a szükséges jegybankpénzt. (Bizonyos korlátozást a bankfelügyeleti tôkemegfelelési szabályok jelentenek a kereskedelmi bankoknál, de ezek is elég ügyesen kezelhetők: pénzügyi innovációk, alárendelt kölcsöntőkék stb.)

A pénzszektor tehát részben termelést, részben fogyasztást hitelez meg. Finanszíroznak termelôvállalkozásokat is hitellel. Az ingatlanberuházásoknál az építési vállalkozók részérôl közvetve finanszírozást, a hitelt felvevôk részérôl azonban vagyoniérték-képzôdést, ha tetszik, bizonyos értelemben fogyasztást finanszíroznak meg. Hiszen ha nem venné meg a hitelfelvevố az ingatlant, akkor fogyasztási kiadásai körében megjelenne a lakásbérlet. Mint az adatok mutatják, egyre inkább eltolódik a bankok tevékenysége a fogyasztási hitelek, sốt alapvetôen az ingatlanhitelezés felé. Ez ugyan a reálkapacitások magasabb kihasználását teszi lehetôvé, de oly módon, hogy minden piaci szereplô túlnyújtózkodik a takaróján, ahogy maga az állam is! Hiszen a deficit finanszírozására kibocsátott állampapírok a jövôbeni adójövedelmeket elôlegezik meg (holott már a tizenkilencedik században állampénzügyi bölcsesség volt, hogy az államnak csak olyan esetekben érdemes eladósodnia, ha beruházásokat hajt végre) (Botos, 2006). A beruházások a jövôben megtermelik a jövedelmeket, amelyekből jut a hitelek szolgálatára. Azért tartotta ezt Kautz Gyula, a Magyar-Osztrák Bank elnöke, jeles közgazdász indokoltnak, ugyanis így az a generáció fizeti meg az államilag finanszírozott infrastruktúra-létesítmények költségeit hitel törlesztésére szolgáló adórészével, amelyik élvezi is annak a létesítménynek a hasznát. Nem lehet ugyanis elvárni, hogy az ilyen hosszú lejáratra térülő, ámde a közösség egészének folyamatosan szükséges beruházásokat a jelenlegi adófizetôk pénzébôl valósítsák meg. A jelen generáció adóját 
kellene hogy megemeljék e célból, de ók csak egy szerény töredékét élveznék a beruházásokkal generált összes haszonnak. Ha tehát van mód a hitelfinanszírozásra, az ilyenkor észszerúnek látszik.

A mai közgazdászok is „felfedezik” ezt a régi bölcsességet. A közelmúltban nagyon tanulságos mú jelent meg a válság kapcsán az ún. „public investment”, tehát a közösségi beruházások finanszírozásáról (Truger, 2015). A szerzô arról ír, hogy az ún. aranyszabály címén kivenné a folyó költségvetés egyenlegébôl a közösségi, jövôbeli versenyképességet megalapozó beruházásokat. Ne kelljen a jelenleg megszorításokra kényszerített országoknak ezek mértékében is folyó költségeiket csökkenteni. Hiszen ez ugyanazt jelentené, mintha megemelnék az adóikat. A csökkenố állami kiadások miatt kényszerúen átvállalt oktatási, egészségügyi költségek ugyanis egyfajta „adót” jelenthetnek a polgárok számára. Ezzel javasolta Truger segíteni azokon az országokon, amelyek napjainkban ilyen lehetôség híján egyre mélyebbre süllyednek a rendkívüli helyzetek miatti megszorítások mocsarába. Nincs beruházás, foglalkoztatásnövelés, adóbevétel, így a válságból nem tudnak kilábalni.

A pénzügyi szektor azonban, mely a finanszírozás révén részesedik minden üzletbôl, egyre növeli részesedését a GDP-bôl, s a vagyona is nô, arányaiban is, a nemzeti vagyon ágazati megoszlásából. Ezt a jelenséget financializációnak nevezzük (BotosBotos, 2014). A financializáció gyakorlatilag a jövedelemdifferenciák növekedésének a következménye. Rengeteg felhalmozott profit van, ami értékpapír formában vár reálberuházási lehetôségre - ha lennének ilyenek. Ezek híján azonban pénzügyi befektetéseket keresgél, s óhatatlanul belebonyolódik az öncélú spekulációba (aminek a reálgazdasági hatások nélküli puszta pénzszerzés csak a célja).

Nyilván egy ponton túl a financializáció sem növekedhet vég nélkül. Eléri a határát, amikor a kamatterhek már a fogyasztás visszafogására kényszerítenek. Ekkor az összkereslet nem bóvül tovább. A jövedelmek ugyanis kellenek a kamatszolgálatra, így nem nô a lakosság fogyasztása. Ekkor már nem lesz értelme a kapacitások bôvítésének, jobb kihasználásának a fogyasztási hitelek terhére. Ahhoz azonban, hogy a jelen termelési szint legalább fennmaradjon, a hitelállománynak nem szabad csökkennie. Ezért olyan kardinális kérdés a hitel mennyisége a gazdaságban! Ha hirtelen lecsökkenne, vissza kellene állnia egy alacsonyabb fogyasztási szintre, hirtelen sok kapacitás válna fölöslegessé. Ez nemcsak a tôke profittermelési lehetôségeit szorítaná vissza, de nagy valószínúséggel a foglalkoztatást is, s máris megindulna a lefelé menô spirál.

A jövedelmeken való végleges osztozkodás rendszerén tehát - mind nemzeti, mind nemzetközi keretekben - változtatni kellene. A fogyasztás növelésére szolgáló jövedelmeket véglegesen oda kellene adni a fogyasztóknak. Csakhogy ez a reálberuházásokat múködtetô tôkések érdekével ütközik! Nem bánják, ha a fogyasztók hitelbôl fogyasztanak, és ezáltal a pénzügyi szektor gyarapszik. Ez már a makroökonómia problémája. Olykor egyébként a cégkomplexum holdingjában benne van maga a pénzügyi intézmény is, így tehát dupla a haszon... (lásd Porsche Bank + Porsche autógyártó cég).

A bérbôl éloók és a profit arányát részben a magánmegállapodások arányosabbá válása segítené, amihez kevesebb remény fúzhetô. Másrészt viszont a progresszívebb, közösségi szükségleteket jobban figyelembe vevô adórendszerek bevezetése javíthatna 
a helyzeten. Azonban ennek megvalósítása sem egyszerú! Különösen, amikor elhitették a társadalommal a „trickle down economy” tételét: a törvényhozók hajlanak a gazdagok számára kedvezó adótörvények meghozatalára, mondván, hogy az „lecsurog” a beruházások révén a szegényebbekhez is. Amit viszont láthatóan nem igazolnak a foglalkoztatási és jövedelmi adatok.

A nemzetközi gazdasági együttmúködésben ugyancsak szükséges lenne radikálisan átalakítani a fejlett és fejlődő országok gazdasági kapcsolatrendszerét. A fejlődőek támogatása a jelenlegi formájában messze nem kielégítő, és kevés a remény, hogy ez megváltozik. Hiszen a globalizmus a kínálkozó előnyök megragadásán alapul, s adottságnak veszi a fejlődô országok szegénységét, az ebből fakadó kényszerúen alacsony béreket. (Holott, bizonyos értelemben ezt maga a globalizmus okozza, amint erre Rodrik és Stiglitz is rámutat.) A fejlődô országoknak alig van esélyük arra, hogy a fejlett országok éles versenye miatt a helyzetükból kitörjenek, hacsak nem a fejlesztố állam koncepciójával, ami azonban minden bizonnyal számos ponton ütközik a globalizmus jelenleg érvényes ,játékszabályaival”.

Enélkül viszont feltétlenül megerôsödhetnek az újkori népvándorlások, pedig már most is erôsen megrázzák a fejlett világot! A fejlett világban a népességfogyás, a fejlődôekben meg a túlszaporodás jelent gondot. A migráció fokozódására már csak azért is sor kerül, mert nemcsak a fejlôdô országokból áramlik ki a sok, megélhetést keresô ember, de a fejlett országok is igényelnek utánpótlást, mivel munkaerőhiánnyal küzdenek. Ez már most erôs szívóhatást jelent. A világ népességben bôvelkedô területein jelentkezô embertöbblet mindenképpen utat tör magának a fejlett világ felé, hacsak a piac nem teremt számukra megélhetést helyben. Pontosabban, az erre kondicionált intézkedésekkel, fejlett országok segítségével létrehozandó piac. Hogy mennyiben jelent e migráció valós megoldást az elöregedô társadalmak problémájára, súlyos kérdés.

\section{ZÁRóGONDOLATOK}

Igazság szerint itt elértünk a közgazdaság határaihoz. Valójában már jogi, sôt, politikai problémákba bonyolódunk. A törvényhozás, a hatalmi mechanizmusok múködése vált problematikussá. Hiszen a jövedelmeken való osztozkodás nem Istentôl kapott törvényeken, hanem emberek által meghozott döntéseken, törvényeken alapul, mint ahogy a pénzteremtés szabályozása és a monetáris politika is. De felmerül a kérdés: a demokráciában kik hozzák a törvényeket? S ezzel már eljutottunk a Stiglitz által teljes világossággal megfogalmazott problémához: annak van joga, akinek pénze van. (Legalábbis az USA-ban így van. Amerikában a leggazdagabbak úgy támogathatják - korlátozás nélkül - a demokratikus választásokat, hogy elérhetik a nekik kedvezô elveket valló jelöltek gyôzelmét. A kampányhoz a média is rendelkezésükre áll, hiszen gyakorlatilag azok is nagy pénzügyi érdekcsoportok kezében vannak. Tömören: a demokrácia válságáról beszélhetünk.)

Maga a tény, hogy az értelmiség nem mentes a politikai befolyásoktól, oda vezet, hogy sikerrel válhatnak uralkodóvá olyan eszmék, amelyek gyakorlatilag csak rétegér- 
dekeket szolgálnak. A többség elfogadja óket, mert elhiszi az értelmiségnek, hogy igaz, amit mond (Stiglitz, 2013). Amerikában ilyen a már idézett „trickle down economy” elve, nálunk pedig a szociális jelzô nélküli, fundamentalista piacgazdaság üdvözítô nézetrendszere. Ez is, mint amerikai „nagybátyja”, abból indul ki, hogy létezik olyan piac, amilyet a tankönyvek feltételeznek: monopóliumok nélküli, kiigazítási mechanizmusokat múködtető rendszer. Nincs járadékvadászat, az adórendszerek igazságosak, a bankszabályozások lazítása kizárólag a hatékonyabb gazdálkodás érdeke. Sajnos ezeket a feltételezéseket a való élet nem igazolja. A piac szorosan összefonódik az állammal. Nálunk a legnagyobb megrendelô az állam; sok helyen az állami támogatástól, a juttatott EU-alapoktól függ a vállalkozások sorsa. Milyen szabadpiac ez? Szerencsére nálunk számos olyan állami beavatkozással is találkozunk, amelyek a fentiekben bírált amerikai jelenségekkel éppen ellentétesek.

Rajan, Stiglitz és mások is leírják, hogy az USA-ban a jogszabályalkotók és az üzleti élet közötti kapcsolat igen erôs. A magas rangú pénzügyi hivatalnokok, döntéshozók szinte átjárnak a cégek igazgatóságaiból az állami hivatalokba, és fordítva. Nyilván nem véletlen az ilyen kapcsolat... Rendkívül erôs a lobbitevékenység az olyan jogszabályokért, amelyek az üzleti élet bizonyos szereplőinek kedveznek. Kiváló példa erre a bankszektor liberalizációja.

Sốt a kialakult helyzet még mélyebb válság eredménye. Ez a válság maga az ökológiai keretfeltételek romlása. Nem akarjuk tudomásul venni, hogy a Föld valóban nem bír el egy dinamikusan növekvő, amerikai életszínvonalat megcélzó embertömeget. Legjobb esetben fenntartható fejlódésról beszél a modern közgazdaságtan. Pedig még ennél is drasztikusabban kellene újrafogalmazni az új szakasz érvényes közgazdaságtanát. Meg kell találni a „no growth” elméletét, ami azt jelenti, hogy a fenntartható Föld, fenntartható társadalom társadalomtudományi szabályainak összességét kell megkeresni, benne a gazdaságét is. Rá kell döbbennünk, hogy milyen hosszú távú pénzügyi tervezéssel lehet méltóságban végigélni az életünket, hogy milyen gazdasági értéke van a gyermekvállalásnak, hogy milyen értelmes és felvilágosult módjai vannak a családtervezésnek, hogy a bóség társadalmának pazarlását meg kell szüntetni, s vissza kell hozni a mértékletesség erényét a társadalmi gyakorlatba. Nevezhetjük ezt Zsolnay László nyomán buddhista közgazdaságtannak is. Mindenesetre az ökológiai közgazdaságtan atyjai, Joseph Cornelius Kumarappa (a nevét sem ismerik hazánkban) és Ernst F. Schumacher (ôt legalább A kicsi szép c. könyvérôl talán) évtizedekkel ezelôtt megfogalmazták azokat a törvényszerúségeket, amelyek a fenntartható élethez kellenek. (Már idéztük Schumachertôl az adekvát technológiát, de nem hangsúlyoztuk eléggé a természet mint tôke értelmezését.) (Botos, 2015a; 2016b.) Márpedig ha nem alakítjuk ki azt az ökológiai gazdaságtant, amely a Naprendszer felé nyitott Földünk energiabiztosítását alapvetô kérdésként kezeli, és a megújuló energiákra rendkívül nagy hangsúlyt fektet, akkor biztos, hogy mégiscsak elérjük Meadows látomását: A növekedés határait.

És a történelem végét; de nem Fukuyama optimista látomásának megfelelóen. A liberális demokrácia ugyanis, úgy tûnik, nem a történelmileg célzatos fejlôdés végpontja. Torzítóan hatnak rá a csoportérdekek és azok önzô piaci képviselői. A liberális demokrácia és a szabadpiac nem alkotnak feltétlenül harmonikus együttest. A szabadpiacot 
eltorzítják, s a polgárokat gyakran félreorientálják. Így azok „demokratikusan” önmaguk érdeke ellen döntenek. Meg kell tehát találni azokat a morális alapokat, amelyeken a demokratikus társadalom múködtethetô, a piac és állam észszerú együttmúködése megvalósítható, és a szabadság és szabályozás megfelelô kombinációja egy fenntartható világ lehetôségét megteremti.

\section{FELHASZNÁLT IRODALOM}

Botos József - Botos Katalin (2014): A kettészakadt ország. In: Fejlesztési stratégiák - Finanszírozási alternatívák. Szerk. Katona Klára, Schlett András, Heller Farkas Könyvek 1., Pázmány Press.

Botos Katalin (2006): Gondolatok az állampénzügyekrôl Kautz Gyula könyve alapján. Statisztikai Szemle, 84. évf., 7. sz., 675-692.

Botos Katalin (2015a): A három tốke: melyik a szúkös elem. Tér - Gazdaság - Ember, 3. évf., 2. sz., 9-23.

Botos, Katalin (2015b): Effects of Income Inequalities: Society and Economy. Public Finance Quarterly, Vol. 60, No. 3, 384-395.

Botos Katalin (2016a): Gandhi harcostársa. Valóság, 59. évf., 8. sz., 1-11.

Botos, Katalin (2016b): Money Creation in the Modern Economy. Public Finance Quarterly, Vol. 61, No. 4, 442-457.

Dardot, Pierre - Laval, Christian (2013): A globálrezon. A neoliberalizmus múltja és jelene. EgyKettô Kiadó, Budapest.

Fukuyama, Francis (1994): A történelem vége és az utolsó ember. Európa Könyvkiadó, Budapest.

Martus Bettina Szandra (2016): Munkahelyteremtés nélküli növekedés: a strukturális változások hatása. Pénzügyi Szemle, 61. évf. 2. sz., 248-268.

Rajan, Raghuram G. (2010): The Fault Lines. How Hidden Fractures Still Threaten the World Economy. Princeton University Press, Princeton.

Reich, Robert B. (1992): The Work of Nations. Vintage Books, New York.

Rodrik, Dani (2015): A globalizáció paradoxona. Demokrácia és a világgazdaság jözoóje. Corvinus Kiadó, Budapest.

Schumacher, Ernst F. (2014): A kicsi szép. Katalizátor Kiadó, Budapest.

Stiglitz, Joseph E. (2013): The Price of Inequality. How Today's Divided Society Endangers Our Future. W. W. Norton \& Company, New York.

Stiglitz, Joseph E. (2016a): The Great Divide. Unequal Societies and What We Can Do About Them. W. W. Norton \& Company, New York.

Stiglitz, Joseph E. (2016b): The Real Issues of the Eurozone and How to Solve Them. Social Europe, 8 September, www.socialeurope.eu/the-real-issues-of-the-eurozone-and-how-to-solve-them.

Truger, Achim (2015): Implementing the Golden Rule for Public Investment in Europe. Materialien zu Wirtschaft und Gesellschaft, 138. Arbeiter Kammer, Wien. 